\title{
Przejęcie struktur sądownictwa w Siedmiogrodzie w 1919 r.*
}

\section{KONTEKST HISTORYCZNY}

Z końcem 1918 r. szeroko rozumiany Siedmiogród (czyli kraina historyczna zwana Siedmiogrodem, powiększona o Marmarosz, Partium i część Banatu) został de facto przyłączony do Rumunii, a przejście tego stanu do stanu de iure zapewnił traktat w Trianon podpisany 4 czerwca $1920 \mathrm{r}$. Rumunia niemal w pełni zrealizowała projekt państwa narodowego, polegający na zespoleniu w jedno państwo obszarów zamieszkanych (również) przez Rumunów. W rzeczywistości jednak uzyskała wieloetniczne terytoria z nierozwiązanymi do dziś problemami mniejszości narodowych. Niniejsza praca koncentruje się na zagadnieniu ekspansji terytorialnej, tj. przejęcia struktur sądowych ${ }^{1}$. Kiedy w grudniu 1918 r. wojska rumuńskie wkroczyły do Siedmiogrodu, traktat pokojowy rozstrzygający ostatecznie losy terytoriów nie został jeszcze zawarty.

* Praca powstała w ramach badań naukowych „Historia prawa prywatnego w Siedmogrodzie XX w.”, finansowanych dzięki stypendium Bolyaiego Węgierskiej Akademii Nauk oraz programowi stypendialnemu Bolyai+ ÚNKP.

1 Jeśli chodzi o ogólny kontekst historyczny tej kwestii, to czytelnik może sięgnąć do następujących prac: I. Romsics, Erdély elvesztése 1918-1947, Budapest 2018; B.L. Balogh, Erdély megszerzése-Románia és az erdélyi kérdés 1918-1920-ban [w:] B.L. Balogh (red.), Erdély megszerzéseRománia és az erdélyi kérdés 1918-1920-ban. Dokumentumok, Budapest 1920. W sprawie przejęcia struktur administracyjnych zob. J. Pál, Föispánok és prefektusok 1918-1919-ben. A közigazgatási átmenet kérdése Erdélyben, „Századok” 2018, nr 6. Warunki społeczno-historyczne z 1918 r. naświetla Z. Szász, Az erdélyi román polgárság szerepéről 1918 öszén, „Századok” 1972, nr 2; ówczesne nastroje podsumowuje I. Mikes, Erdély útja Nagymagyarországtól Nagyromániáig, t. I-II, Brassó 1931; ogólny kontekst historyczny: M. Ormos, Padovától Trianonig 1918-1920, Budapest 1983; B. Ablonczy, Trianon-legendák, Budapest 2010. 
Upraszczając skomplikowaną sytuację wojskową, można powiedzieć, że na mocy rozejmu zawartego w Belgradzie 13 listopada 1918 r. rząd węgierski zmuszony był wycofać się z terenów położonych na wschód od górnego biegu rzeki Samosz i na południe od Maruszy². Armia rumuńska zajęła te tereny już w następnych dniach. Inicjatywa zawarcia rozejmu w Belgradzie wyszła od rządu Károlyiego. Korzyści rozejmu były kontrowersyjne - ponieważ zawierał nakaz opuszczenia terenów, w rzeczywistości był mniej korzystny od zawieszenia broni zawartego w imieniu Austro-Węgier w Villa Giusti 3 listopada 1918 r. Rozejm w Villa Giusti odnosił się do działań zbrojnych na wszystkich frontach i zawierał adnotację, że wojska Ententy powstrzymają się od przekroczenia tej linii, co było przez nie respektowane aż do momentu podpisania porozumienia.

W dniu 1 grudnia 1918 r. Zgromadzenie Narodowe w Gyulafehérvár (rum. Alba Iulia) proklamowało przyłączenie Siedmiogrodu do Rumunii, zwane „zjednoczeniem". Wkrótce wojska rumuńskie przekroczyły ustaloną w rozejmie belgradzkim linię demarkacyjną i rozpoczęły aneksję węgierskich terytoriów obiecanych Rumunii w tajnym układzie z Ententą z 1916 r. Węgrzy musieli sobie jeszcze przyswoić ten nowy sposób prowadzenia polityki. W swoich pamiętnikach Ernő Garami ${ }^{3}$ notuje, że Ioan Erdélyi, budapeszteński przedstawiciel Rady Rządzącej z Sybinu (węg. Nagyszeben, rum. Sibiu), powiedział mu: „Drogi panie ministrze, jak mogliście być tak naiwni, żeby sądzić, iż będziemy ten rozejm respektować choćby przez chwilę? Cóż mogłem mu odpowiedzieć? Tak, istotnie naiwnością było wierzyć w nietykalność umowy"4. A były minister obrony Albert Bartha w styczniu 1919 r. oświadczył przy jakiejś okazji, że ponowne naruszenie traktatu o zawieszeniu broni stało się możliwe dlatego, że „nie ma takiej siły, która by zmusiła do respektowania umowy tych, którzy ją zeszmacili’’5. Pokojowa, przyjazna Entencie polityka Mihálya Károlyiego zawiodła.

Od chwili przekroczenia rzeki Maruszy wojsk rumuńskich nie można uznać za armię okupującą w imieniu Ententy, tylko za najeźdźcę łamiącego porozumienie o zawieszeniu broni i rozejm w Belgradzie. Nie ma jednak wątpliwości, że to działanie niezmiennie cieszyło się silnym poparciem politycznym ze strony Francji ${ }^{6}$ Kluż (węg. Kolozsvár, rum. Cluj-Napoca) został zajęty 24 grudnia

${ }^{2}$ M. Ádám, M. Ormos (red.), Francia diplomáciai iratok a Kárpát-medence történetéröl 1918-1919, Budapest 1999, dokument nr 9.

${ }^{3}$ Polityk, socjaldemokrata, minister handlu od 31 października 1918 r. do 21 marca 1919 r.

${ }^{4}$ E. Garami, Forrongó Magyarország. Emlékezések és tanulságok, Budapest 1989, s. 80.

${ }^{5}$ I. Romsics, Erdély elvesztése..., s. 161.

${ }^{6}$ W podpisanym 17 sierpnia $1916 \mathrm{r}$. w Bukareszcie tajnym układzie Ententa istotnie obiecała Rumunii Siedmiogród, potem jednak Rumunia została zwyciężona przez armię niemiecką i austro-węgierską, wskutek czego była zmuszona zawrzeć osobny rozejm (7 maja 1918 r.), dlatego warunki uzyskania terytorium określone $\mathrm{w}$ traktacie bukareszteńskim nie zostały spełnione. Zgodnie z art. 5 tajnej umowy strony zobowiązały się, że osobny rozejm lub ogólny traktat pokojowy będą zawierać 
1918 r. ${ }^{7}$ Armia rumuńska dotarła na razie do Karpat Zachodnich. W styczniu 1919 r. front zatrzymał się na linii Vaskoh (rum. Vașcău) - Csucsa (rum. Ciucea) - Zilah (rum. Zalău) - Nagybánya (rum. Baia Mare) - Syhot Marmaroski (węg. Máramarossziget, rum. Sighetu Marmației) ${ }^{8}$, mimo że Rumuni chcieli kontynuować ofensywę w głąb państwa węgierskiego. W marcu Francja zezwoliła na dalszą inwazję (nota Vyxa), czemu sprzeciwił się jednak rozczarowany już wtedy aliantami Mihály Károlyi, który chciał przekazać władzę w ręce socjaldemokratów, wierząc jednocześnie w pomoc ze strony bolszewickiej Rosji. Tymczasem socjaldemokraci doszli do porozumienia z komunistami i wspólnie ogłosili powstanie Węgierskiej Republiki Rad, co jeszcze bardziej osłabiło międzynarodową pozycję Węgier.

Odpowiedzią aliantów na powstanie Węgierskiej Republiki Rad była interwencja wojsk rumuńskich, która rozpoczęła się 16 kwietnia 1919 r. Pod koniec miesiąca wojska rumuńskie zajęły Kraj Zacisański. Etapowość posuwania się armii rumuńskiej wpłynęła również na przejęcie systemu sądowego. Wykorzystując niezwykle trudną sytuację militarną i polityczną Węgier oraz panujący w kraju kryzys ekonomiczny, 30 lipca 1919 r. wojska rumuńskie przekroczyły nawet Cisę. 1 sierpnia 1919 r. Republika Rad upadła i 4 sierpnia Rumuni wkroczyli do Budapesztu ${ }^{9}$, skąd zaczęli się wycofywać w listopadzie.

Istotne jest także to, że podczas gdy armia rumuńska stopniowo zajmowała Siedmiogród, węgierski system sądowy istniał i funkcjonował. Struktury sądownicze zostały przejęte przez państwo rumuńskie w $1919 \mathrm{r}$. W niniejszym artykule zagadnienie to będzie analizowane na podstawie trzech przypadków: losu sądów w Klużu ${ }^{10}$, Izby adwokackiej w Marosvásárhely (rum. Târgu Mureş) oraz działalności sądownictwa w Sepsiszentgyörgy (rum. Sfântu Gheorghe). Znaczenie tego tematu wynika z faktu, że zarówno w klasycznej, jak i najnowszej literaturze

wyłącznie wspólnie i jednocześnie. W związku ze wsparciem politycznym Francji na szczególną uwagę zasługuje rola generała Henri Berthelota.

7 Dwa dni wcześniej, 22 grudnia, w Klużu odbyło się Węgierskie Zgromadzenie Narodowe jako protest przeciwko decyzji Rumuńskiego Zgromadzenia Narodowego w Gyulafehérvár o zjednoczeniu z Rumunią. Protest dotyczył zasadniczo tego, że zjednoczenie Siedmiogrodu z Rumunią bez konsultacji z Węgrami jest niezgodne z prawem.

${ }^{8}$ Węgrzy nie stawiali dotąd oporu rumuńskiej ekspansji terytorialnej, z jednej strony dlatego, że nie mieli wojsk gotowych do działania, a z drugiej strony - że Károlyi zbyt późno, bo dopiero w marcu 1919 r., zdał sobie sprawę, że pokojowa, przyjazna Entencie polityka zawiodła.

${ }^{9} \mathrm{Na}$ cześć setnej rocznicy rumuńskiej okupacji, podczas której systematyczne grabieże w Budapeszcie i okupowanych częściach kraju były na porządku dziennym, Dziennik Ustaw opublikował w Bukareszcie pamiątkowy album, wskazując, że również na ten temat Węgry i Rumunia mają zasadniczo odmienne poglądy. Por. A.-V. Matei, D.-C. Obreja, S. Mărgărit, Centenarul intrării armatei române în Budapesta, Monitorul Oficial, Bukarest 2019.

${ }^{10}$ W Klużu działał sąd apelacyjny, okręgowy oraz rejonowy dla miasta i dla prowincji. 
naukowej poświęconej utracie Siedmiogrodu kwestia przejęcia wymiaru sprawiedliwości poruszana jest co najwyżej marginalnie, albo i wcale ${ }^{11}$.

\section{PRZEJĘCIE SĄDÓW (APELACYJNEGO, OKRĘGOWEGO I REJONOWEGO) W KLUŻU}

W dniu 1 grudnia 1918 r. Zgromadzenie Narodowe w Gyulafehérvár oprócz proklamacji zjednoczenia Siedmiogrodu z Rumunią obiecało wszystkim wspólnie mieszkającym narodom pełną swobodę narodową, w ramach której zagwarantowano także wymiar sprawiedliwości we własnym języku, reprezentowany przez osoby należące do danego narodu. Było to tylko jedno z wielu zobowiązań, których państwo rumuńskie nie dotrzymało ${ }^{12}$. Następnego dnia po Zgromadzeniu Narodowym rumuńska Rada Rządząca Siedmiogrodu ${ }^{13}$ szefem wymiaru sprawiedliwości (a właściwie ministrem) mianowała dr. Aurela Lazăra (1872-1930), prawnika z Nagyvárad (rum. Oradea) ${ }^{14}$. Siedziba Rady Rządzącej znajdowała się w Sybinie ${ }^{15}$. Zgodnie z dekretem Rady Rządzącej zatwierdzonym 1 stycznia 1919 r. przepisy obowiązujące przed 18 października 1918 r. (kiedy to Alexandru Vaida-Voevod ogłosił w budapeszteńskim parlamencie deklarację o prawie do samostanowienia Rumunów z Siedmiogrodu) ${ }^{16}$ miały pozostać w mocy tymczasowo, aż do odwołania, w celu utrzymania porządku publicznego i ciągłości prawa. Dekret stanowił

${ }^{11}$ Tylko o przejęciu administracji traktuje np. I. Mikó, Huszonkét év - az erdélyi magyarság politikai története 1918. december 1-töl 1940. augusztus 30-ig, Budapest 1941; I. Romsics, Erdély elvesztése....

${ }^{12}$ Dekret z mocą ustawy nr 3631 z 1918 r. z Proklamacji w Gyulafehérvár ratyfikował jedynie zjednoczenie (Dziennik Urzędowy, 13 grudnia 1918 r., 212).

${ }^{13}$ Consiliul Dirigent Român al Ardealului.

${ }^{14}$ Romsics podaje, że Lazăr kierował działem finansów, nie odpowiada to jednak faktom. Por. I. Romsics, Erdély elvesztése..., s. 136. Za kwestie prawne odpowiadały aż trzy osoby: Lazăr za sądownictwo, Emil Haţieganu za prawodawstwo i Ioan Suciu za przygotowanie konstytucji. Iuliu Maniu był odpowiedzialny za sprawy wewnętrzne, Vasile Goldiș za kwestie religijne, edukacyjne i mniejszościowe, Ștefan Cicio-Pop za kwestie wojskowe i bezpieczeństwo publiczne, a Alexandru Vaida-Voevod za sprawy zagraniczne i kontakty medialne. Do Aurela Vlada należały finanse, do Victora Bontescu - rolnictwo i handel, do Romula Boilă - transport, telekomunikacja i żywność, do Iona Flueraşa - problemy społeczne i zdrowie, a do Iosifa Jumanca - przemysł. Valeriu Branişte, Vasile Lucaciu i Octavian Goga byli w Radzie Rządzącej ministrami bez teki. W okresie działalności Rady miało miejsce kilka zmian organizacyjnych i personalnych.

${ }^{15}$ Armia rumuńska zajęła Sybin już w listopadzie $1919 \mathrm{r}$.

${ }^{16}$ Słowa o przystąpieniu do Rumunii nie padły w deklaracji bezpośrednio, wynikały jednak z jej treści: naród rumuński na Węgrzech chce jako naród skorzystać z prawa do stanowienia o swojej przynależności państwowej bez jakiegokolwiek obcego wpływu, ponieważ o pozycji narodu rumuńskiego na Węgrzech w obrębie terytorium własnego państwa nie może decydować nikt inny, jak własne zgromadzenie narodowe. O Alexandru Vaida-Voevod zob. B.L. Balogh, A föderalizmustól az egyesülésig. Alexandru Vaida-Voevod és Nagy-Románia megteremtése, „Pro Minoritate” 2018, nr 2. 
również, że wszyscy wybrani lub mianowani urzędnicy mogą pozostać na swoich stanowiskach. Dla dobra urzędu i w interesie spokoju publicznego można było jednak każdego z nich (sędziego, notariusza) przenieść lub wysłać na emeryturę. Przepisy węgierskiego prawa dotyczące zakazu przenoszenia sędziów lub notariuszy bez ich zgody zostały uchylone ${ }^{17}$. Kompetencje prezesów sądów apelacyjnych i prokuratorów w zakresie kontroli przejął członek Rady Rządzącej odpowiedzialny za wymiar sprawiedliwości. Językiem urzędowym, a więc używanym również w strukturach sądowniczych, stał się rumuński. Na mocy ww. dekretu węgierska ustawa nr XLIV z 1868 r. w sprawie równości poszczególnych narodowości wobec prawa obowiązywała do czasu uchwalenia ostatecznej regulacji, z tą poprawką, że zamiast języka węgierskiego należało rozumieć język rumuński. Zdaniem Rady Rządzącej ustawę o mniejszościach narodowych należało stosować „lojalnie”, czyli tak, żeby w tych komitatach, gdzie jedną piątą ludności stanowiła mniejszość narodowa, stosowana była zasada, że każdy ma prawo do używania języka ojczystego przed organami administracji publicznej i wymiaru sprawiedliwości. W dekrecie tym niewątpliwie wykazano pewną wrażliwość na kwestię mniejszości. Przykładowo, usankcjonowano w nim użycie nazw miejscowości we wszystkich językach mniejszości narodowych i uchylono węgierską ustawę nr IV z 1898 r. w sprawie nazewnictwa miejscowości i innych nazw geograficznych.

W departamencie sprawiedliwości Rady Rządzącej dyrekcję działu praw cywilnych powierzono dr. Corneliu Crăciunescu, adwokatowi z Temeszwaru (węg. Temesvár, rum. Timișoara), dyrekcję działu praw karnych - dr. Victorowi Andru, a dyrekcję działu rachunkowości (gospodarczego) - dr. Ionowi Iancu. Na stanowisko sekretarza referatu ds. sądowych powołany został dr Alexandru Marta, który zajmował je od 1 marca 1919 r. Alexandru Marta prowadził wcześniej praktykę adwokacką w Lippa (rum. Lipova), a od 1915 r. pełnił funkcję sędziego sądu apelacyjnego w Segedynie, posługując się nazwiskiem Sándor Marta. To on dostał misję zorganizowania siedmiogrodzkiego sądownictwa. Ioan P. Papp ${ }^{18}$ opisał go w następujący sposób:

17 Przykładowo, zgodnie z art. 15 ustawy nr IV z 1869 r. o sprawowaniu władzy sądowniczej „mianowanego ustawowo sędziego nie można odwołać ze stanowiska, z wyjątkiem przypadków i w sposób określony przez prawo”. A zgodnie z art. 16 ,z wyjątkiem przypadków określonych przez prawo sędzia może zostać przeniesiony lub awansowany ze swojego miejsca do innego sądu lub innego urzędu tylko za jego zgodą. Wyjątek od tej zasady dopuszcza się tylko wtedy, gdy awans lub przeniesienie do innego sądu wynika ze zmiany organizacji sądowej; jak również jeśli członek rodziny sędziego jest lub ma być zatrudniony w tym samym sądzie. Sędzią tego samego sądu nie można mianować: krewnych wstępnych lub zstępnych; spokrewnionych ze sobą w linii bocznej do trzeciego stopnia lub spowinowaconych do drugiego stopnia, jak również pozostających w związku adopcyjnym".

${ }_{18}$ Ioan Paul Papp (1878-1959) urodził się w Belényes (rum. Beiuș), uzyskał doktorat z prawa w Klużu i w latach 1903-1919 wykonywał zawód adwokata w Bradzie. W 1919 r. przez krótki czas pracował w Radzie Rządzącej, ale w tym samym roku został powołany na sędziego rumuńskiego składu orzekającego w Klużu. W latach 1920-1923 był sędzią rumuńskiej komisji sędziowskiej 
[...] ten niepozorny z wyglądu, dynamiczny, energiczny, dysponujący niezłomną wolą, zagorzały i nieugięty Rumun, patriota wielki o bezkresnej kulturze prawniczej to absolutny znawca struktur sądowych i regulujących je rozlicznych norm, a przy tym nieskalany, uczciwy, odważny człowiek o wyjątkowej pracowitości... ${ }^{19}$

Pierwszym zadaniem dr. Alexandru Marty ${ }^{20}$ było przejęcie sądownictwa ${ }^{21}$.

Rozporządzenie nr 121 departamentu sprawiedliwości Rady Rządzącej ukazało się w Dzienniku Urzędowym z dnia 19 lutego 1919 r. Na jego mocy sądownictwo działające w Siedmiogrodzie zostało oddzielone od sądownictwa państwa węgierskiego i stało się częścią sądownictwa Rumunii. Rozciągało się tylko na część byłego węgierskiego terytorium państwowego przyłączonego obecnie do Rumunii, tj. na obszary podlegające właściwości sądów apelacyjnych w Kluż i Marosvásárhely. Zasięg obowiązywania rozporządzenia rozszerzono na tereny leżące za linią demarkacyjną w lipcu (dla Partium) $)^{22}$ i we wrześniu (dla Banatu) ${ }^{23} 1919$ r. ${ }^{24}$ Tym samym jurysdykcja węgierskiego Sądu Najwyższego nad Siedmiogrodem wygasła. Wszystkie sprawy, które powinny były zostać przesłane do Sądu Najwyższego w celu rozpatrzenia, zostały zawieszone do odwołania, później zaś, w grudniu 1919 r., w Sądzie Kasacyjnym w Bukareszcie utworzono oddział ds. Siedmiogrodu w celu zastosowania prawa partykularnego. Kierownik departamentu sprawiedliwości Rady Rządzącej miał uprawnienia kontrolne nad sądownictwem. Również to rozporządzenie wyraźnie potwierdziło, że węgierskie normy prawa materialnego i formalnego na razie pozostały w mocy.

Wprowadzono obowiązek złożenia przysięgi, której tekst brzmiał następująco:

w Nagyvárad, następnie do 1940 r. sędzią rumuńskiego sądu apelacyjnego w Klużu, potem przeprowadził się do Sybinu, gdzie od 1939 r. był prezesem rumuńskiego sądu apelacyjnego.

19 I.P. Papp, Instaurarea justiției românești în Ardeal, „Transilvania” 1945, nr 1-2, s. 4.

${ }^{20}$ Później został prezesem rumuńskiego sądu apelacyjnego w Temeszwarze, w 1938 r. przeszedł na emeryturę jako sędzia.

${ }^{21}$ Rumuńskie materiały archiwalne dotyczące przejęcia sądów publikuje G. Iancu (red.), Justiție română în Transilvania (1919), Kluż-Napoka 2006.

22 Rozporządzenie $\mathrm{nr} 1200 \mathrm{z} 1919 \mathrm{r}$.

${ }^{23}$ Rozporządzenie nr 6267 z 1919 r.

${ }^{24}$ Terytoria te znalazły się bowiem pod okupacją armii rumuńskiej po ataku na Republikę Rad 16 kwietnia 1919 r. W odniesieniu do przejęcia sądów w Banacie zanotowano, co następuje: „Również przejęcie sądów sprawiało trudności, ponieważ większa część składów sędziowskich, jak na przykład sędziowie sądu okręgowego i rejonowego w Karánsebes (rum. Caransebeş) pod kierownictwem Jánosa Czikó, co więcej, cały personel pomocniczy odmówił złożenia przedwcześnie żądanej przysięgi i opuścił swoje miejsca. W tych okolicznościach w pierwszych strukturach nowej władzy państwowej otrzymali pracę nawet ci, którzy nie mieli do tego odpowiednich kwalifikacji intelektualnych ani moralnych, wyrządzając tym samym nieobliczalne szkody interesom publicznym i jednostkom". Zob. E. Jakabffy, G. Páll, A bánsági magyarság húsz éve Romániában (1918-1938), Budapest 1939, s. 32. 
Ja, ..., przysięgam na Boga Wszechmogącego, że dochowam wierności królowi Ferdynandowi I i państwu rumuńskiemu, będę wiernie strzegł praw i przepisów Rumunii, respektował rozporządzenia Rady Rządzącej ${ }^{25}$, a z powierzonych mi obowiązków wywiążę się rzetelnie, sumiennie i bezstronnie. Przyrzekam dochować tajemnic zawodowych. Tak mi dopomóż Bóg!26

Rozporządzenie zezwalało również na rotę bez formuł religijnych. Złożenie przysięgi należało zaprotokołować. Sankcją za odmowę złożenia przysięgi była nie tylko utrata urzędu, ale także nieuznanie przez państwo rumuńskie uprawnień emerytalnych. W przypadku adwokatów i notariuszy odmowa złożenia przysięgi skutkowała zakazem dalszego wykonywania zawodu. Natomiast tym, którzy złożyli przysięgę, państwo rumuńskie uznawało lata służby i nabyte prawa ${ }^{27}$. Jeszcze w styczniu, kiedy w związku z przejęciem administracji pojawiła się kwestia składania przysięgi, Emil Grandpierre ${ }^{28}$, były sędzia sądu okręgowego i nadżupan Klużu, na czele odpowiedniego komitetu prowadził w Sybinie negocjacje z Iuliu

${ }^{25} \mathrm{~W}$ przekładzie dosłownym z jęz. rumuńskiego: „święcie przestrzegał”.

${ }^{26}$ „Jur pe atotştiutorul Dumnezeu, de a fi credincios Regelui Ferdinand I şi Statului Român, de a respecta cu sfinţenie legile țării şi decretele, ordonanţele Consiliului Dirigent, şi de a îndeplini cu onoare, conştiinţă şi nepărtinire funcţiunile ce îmi sunt încredinţate şi a păstra secretul oficios. Aşa să-mi ajute Dumnezeu”. Jak pisze Imre Mikó, odmawiając złożenia przysięgi na wierność, „węgierscy urzędnicy państwowi stracili źródła utrzymania i woleli wybrać nędzę zamiast zdradzać narodowe cele. Odmowa ślubowania była pierwszą samoświadomą manifestacją Węgrów, która skuła społeczność w Siedmiogrodzie w trwałą węgierską jedność. Rozpaczliwa sytuacja węgierskiej narodowości zmusiła wielu z nich, zwłaszcza urzędników państwowych, do opuszczenia Siedmiogrodu. Przez długie lata pociągi repatriacyjne przywoziły do Pesztu kwiat węgierskiej inteligencji, tych, którzy... popełnili ,wielki siedmiogrodzki grzech”: skazani na poniewierkę w wagonach kolejowych na budapeszteńskich torowiskach, próbowali stworzyć sobie nową ojczyznę... Według danych Narodowego Urzędu ds. Uchodźców liczba uciekinierów z Siedmiogrodu w 1918 r. wynosiła 40952 osób, w 1920 r. 70 773, w 1921 r. 19 879, w 1922 r. 13 651, w 1923 r. 7536, a w 1924 r. 1693, co oznacza, że w ciągu siedmiu lat z Siedmiogrodu przeniosło się do okrojonej ojczyzny ogółem 197035 Węgrów...”. Por. Mikó, Huszonkét év - az erdélyi magyarság politikai..., s. 16-17.

${ }^{27}$ Po zawarciu traktatu w Trianon państwo rumuńskie ponownie otworzyło możliwość zaprzysiężenia.

${ }^{28}$ Emil Grandpierre (1874-1938), sędzia sądu okręgowego, potem nadżupan, następnie jeden z najwybitniejszych przedstawicieli węgierskiego życia politycznego w Siedmiogrodzie. W 1925 r. przeprowadził się na Węgry i pracował jako sędzia administracyjny, całkowicie rezygnując z życia publicznego. W 1926 r. pod pseudonimem Péter Nagy (Piotr Wielki) opublikował książkę zatytuowaną Ó, kedves Kolozsvár! (Och, drogi Kolozsvárze!). Sándor Reményik pisze, że książka ta to stonowane, po męsku dyskretne, ale mocne w wymowie, poważne wyznanie miłości do rodzinnego miasta autora... Również wspomniane dzieło wskazuje na moralne brzemię związane z opuszczeniem Kluża. W 1928 r. autor oświadczył: „Mieszkam, pracuję i czuję się najlepiej, kiedy mogę być w Siedmiogrodzie, w moim ogrodzie w Klużu. Ponieważ w ubiegłym roku z wielkimi trudnościami co prawda, ale dostałem wizę. Owszem, zajęło mi to pół roku, ale dostałem i przez kilka tygodni mogłem się cieszyć moim ogrodem”. Por. M. Móricz, Grandpierre Emil csak a munkájának él, a közéleti szerepléstöl teljesen visszavonult, „Brassói Lapok” z 20.12.1928 r., s. 6. 
Maniu. Komitet wnioskował, żeby - dopóki ostateczny status Siedmiogrodu nie zostanie rozstrzygnięty traktatem pokojowym - zamiast przysięgi na wierność można było ślubować zgodne z prawem i skuteczne wypełnianie obowiązków. Rada Rządząca odrzuciła ten wniosek ${ }^{29}$.

Językiem obowiązującym w sądownictwie stał się język rumuński, jednak w kwestii używania języków mniejszościowych rozporządzenie nr 121 odsyłało do dekretu Rady Rządzącej z dnia 1 stycznia 1919 r. W celu dokonania zmiany obowiązującego języka należało ustalić okres przejściowy, ponieważ znaczna liczba sędziów, prokuratorów, urzędników, notariuszy i adwokatów nie znała języka rumuńskiego. Dlatego w rozporządzeniu przewidziano na naukę języka rumuńskiego 12 miesięcy dla sędziów i pracowników sądownictwa oraz 6 miesięcy dla adwokatów i notariuszy. Nota bene Ioan P. Papp skomentował, że tekst rozporządzenia nie jest jeszcze płynny i potoczysty, rumuński język prawny był bowiem nadal „nieco obcy” jego redaktorom ${ }^{30} .12$ lutego 1919 r. Rada Rządząca powołała nowe kierownictwo w organach wymiaru sprawiedliwości.

Podczas planowania personelu sądownictwa liczono się z tym, że węgierscy sędziowie odmówią złożenia przysięgi. Według Ioana P. Pappa na obszarach podlegających właściwości sądów rejonowych w Kluż i Marosvásárhely liczba Węgrów, którzy złożyli przysięgę, była minimalna i nie miała żadnego praktycznego znaczenia $^{31}$. Dlatego punktem wyjścia byli zatrudnieni w sądownictwie węgierskim sędziowie i urzędnicy rumuńskiego pochodzenia. Jeśli chodzi o sądownictwo węgierskie, to w 1918 r. w Sądzie Najwyższym pracowało dwóch sędziów rumuńskiego pochodzenia (George Plopu, Ioan Jurca), w sądach apelacyjnych siedmiu (Micșa Pompei, Adrian Nistor, Gheorghe Popa, Gavril Chindriş, Alexandru Marta), w sądach okręgowych 20, w sądach rejonowych 41, a liczba aplikantów wynosiła $36^{32}$. Do nich dołączyło wielu adwokatów rumuńskiego pochodzenia działających na terenie Siedmiogrodu oraz sędziów z terytorium starego królestwa, czyli Rumunii sprzed $1918 \mathrm{r}$.

Przejęcie sądów okręgowych rozpoczęło się 4 marca 1919 r. w Sybinie ${ }^{33}$. W swoich wspomnieniach Ioan P. Papp pisze: „tu, gdzie rezyduje Rada Rządząca, nie można było już dłużej tolerować tego gniazda magistratusów opłacanych i instruowanych przez obce mocarstwo, którzy obserwowali władzę rumuńską w Siedmiogrodzie wyzywającym, prowokacyjnym i sarkastycznym wzro-

${ }^{29}$ N. Bárdi, Az erdélyi magyarok Romániában 1918-1922, „História” 2008, nr 6-7, s. 16.

${ }^{30}$ I.P. Papp, Instaurarea justiției românești..., s. 7.

${ }^{31}$ Ibidem, s. 10.

32 Ibidem, s. 17-18.

${ }^{33}$ Natomiast przejęcie sądu rejonowego w Vajdahunyad (dziś: Hunedoara) miało miejsce już pod koniec lutego. 
kiem"34. W Sybinie trzeba było użyć siły, ponieważ węgierski zarząd odmówił przekazania sądu okręgowego nowo mianowanemu rumuńskiemu prezesowi, Iuliu Munteaunu. Z 17 sędziów przysięgę na wierność złożyło trzech, a z 9 urzędników sądowych jeden. Przysięga odbierana była jako uznanie najwyższej władzy rumuńskiej, a przy braku traktatu pokojowego jako akt przedwczesny, uważano ją zatem za zdradę ojczyzny. W publicznej świadomości przysięga lojalności funkcjonowała nawet jako czynnik mający wpływ na negocjacje pokojowe: skoro konferencja pokojowa nie zdecydowała jeszcze o losie danego obszaru, a mimo to węgierscy urzędnicy ślubują wierność królowi rumuńskiemu, to przysięga uznawana była za poparcie dla połączenia z Rumunią. W takich okolicznościach nie dziwi niezwykle wysoka liczba osób odmawiających złożenia przysięgi na wierność zarówno w administracji, jak i w sądownictwie.

Przejęcie sądu apelacyjnego i okręgowego w Klużu miało miejsce 11 marca 1919 r. Na czele sądu apelacyjnego stanął nowo mianowany prezes, dr Micșa Pompei, a na czele sądu okręgowego - dr Laurenţiu Nestor. Tu także trzeba było użyć siły. Złożenia przysięgi odmówili wszyscy pracownicy sądu apelacyjnego, z wyjątkiem saskiego sędziego, Gustava Haupta. Dla porządku należy przypomnieć, że 8 stycznia 1919 r. na zgromadzeniu w Medgyes (rum. Mediaș) Sasi siedmiogrodzcy poparli przyłączenie Siedmiogrodu do Rumunii. Kolejne sądy okręgowe należące do jurysdykcji sądu apelacyjnego w Klużu zostały przejęte 13 marca (Gyulafehérvár, Deva, Torda), 19 marca (Bystrzyca, węg. Beszterce, rum. Bistrița) i 26 marca (Dézs, rum. Dej). Sąd apelacyjny w Marosvásárhely przejął 18 marca nowo mianowany prezes, Romul Popp.

Szczegóły przejęcia sądu apelacyjnego w Klużu zachowały się w raporcie z 13 marca 1919 r., przekazanym departamentowi sprawiedliwości Rady Rządzącej przez dr. Micşa Pompei. Sędzia zreferował, że na dzień 11 marca zwołał sesję plenarną sądu apelacyjnego, z zastrzeżeniem, że nieuzasadniona nieobecność będzie jednoznaczna z odmową złożenia przysięgi. Oprócz Gustava Haupta nikt się jednak nie zjawił, odmówiono nawet podpisu na potwierdzeniu przyjęcia posiedzenia do wiadomości. W imieniu nieobecnych sędziów złożono oświadczenie odzwierciedlające stanowisko wszystkich pracowników, z wyjątkiem prezesa Györgya Weéra, który od ośmiu miesięcy był obłożnie chory, oraz sędziów Adriana Nyisztora i Iosifa Szepessiego, również chorych. W związku z tym nie można było sporządzić protokołu z odmowy złożenia przysięgi. Gustav Haupt, nowo mianowany Iuliu Popescu, jak również prokurator Alexandru Pop złożyli przewidzianą rozporządzeniem nr 121 przysięgę. Nowo mianowani sędziowie Andrei Pop i Sever Barbura nie zjawili się.

\footnotetext{
${ }^{34}$ I.P. Papp, Instaurarea justiției românești..., s. 11.
} 
Z budynku sądu apelacyjnego usunięto inskrypcję: „Niech ten gmach nieustannie podsyca w narodzie szacunek dla praworządności, miłość do prawa i sprawiedliwości oraz głosi wszem i wobec sędziowskie cnoty"35.

Sporządzono także protokół przejęcia sądu, który ujawnił interesujące szczegóły. O wpół do dziesiątej rano przed Antalem Pozsonyim, wiceprezesem sądu, stawił się dr Micșa Pompei, sędzia apelacyjny, który oświadczył, że na mocy rozporządzenia nr 1919/121 został mianowany prezesem sądu apelacyjnego w Klużu i otrzymał polecenie przejęcia sądu, w związku z czym wezwał Antala Pozsonyiego do przekazania sądu. Antal Pozsonyi odmówił, powołując się na porozumienie o zawieszeniu broni i konwencje haskie. Wówczas dr Micșa Pompei oddalił się, żeby około godziny 10 wrócić w towarzystwie dr. Iuliana Popa, burmistrza Klużu, który występował również w zastępstwie prefekta miasta, dr. Valentina Poruțiuta, będącego jednocześnie lokalnym przedstawicielem Rady Rządzącej. Ponownie wezwali Pozsonyiego do przekazania sądu apelacyjnego, zwracając mu uwagę, że mają do dyspozycji wojsko.

Antal Pozsonyi złożył następujące oświadczenie ${ }^{36}$ :

W zastępstwie obłożnie chorego prezesa, odpowiadając w tej trudnej sytuacji na usłyszane przed chwilą wezwanie, jako wiceprezes sądu apelacyjnego w Klużu, muszę złożyć następujące oświadczenie, które ze względu na moją pozycję i odpowiedzialność mogę oprzeć wyłącznie na przepisach prawnych.

My, węgierscy sędziowie i pracownicy wymiaru sprawiedliwości, którzy zostaliśmy powołani na podstawie węgierskich przepisów, a więc zgodnie z prawem, ślubowaliśmy zachować wierność państwu węgierskiemu, jego konstytucji, prawom i obyczajom w każdych okolicznościach. $Z$ tej przysięgi nikt nas nie zwolnił.

Zgodnie z par. I konwencji wojskowej zawartej z najwyższym dowódcą wojsk alianckich Ententy administracja cywilna pozostaje w rękach rządu węgierskiego ${ }^{37}$.

Zgodnie $\mathrm{z}$ art. XVII alianci nie ingerują $\mathrm{w}$ wewnętrzną administrację państwa węgierskiego.

W art. 1 komunikatu wydanego 24 grudnia 1918 r. dowódca VII batalionu rumuńskiej armii okupacyjnej oświadczył, że Kluż został zajęty przez wojska rumuńskiej armii królewskiej na rozkaz mocarstw Ententy, wyłącznie w celu zachowania porządku państwowego, dla bezpieczeństwa życia i mienia.

$\mathrm{W}$ art. 3 komunikatu, zgodnie z porozumieniem o zawieszeniu broni, dowódca zapewnił, że wszystkie urzędy państwowe, administracyjne, gminne i tym podobne

${ }^{35}$ Tablica z inskrypcją nie została zniszczona, do dziś jest zamknięta w pomieszczeniu sądowym.

${ }^{36}$ Oryginalny tekst oświadczenia w języku węgierskim nie był do dyspozycji autora, który z powodu epidemii COVID-19 nie mógł dokończyć kwerendy archiwalnej. Stąd autor przytacza węgierski tekst oświadczenia na podstawie dokumentu zawierającego przekład oświadczenia na język rumuński. Autor zamierza w przyszłości kontynować badania nad tematem.

${ }^{37}$ Chodzi o rozejm w Belgradzie z 13 listopada 1918 r. Szerzej: M. Ormos, A belgrádi katonai konvencióról, „Történelmi Szemle” 1979, nr 1. 
będą nadal działać za pośrednictwem dostępnych organów na podstawie istniejących przepisów ustawowych i wykonawczych.

Wspomniane porozumienie o zawieszeniu broni jest wiążące dla Rumunii, która działa w imieniu Ententy, i, jak jasno z tego wynika, jest też wiążące dla wszystkich Rumunów, którzy występują na podstawie odnośnej proklamacji z Gyulafehérvár oraz dla tych, którzy po zjednoczeniu uważają się za obywateli Rumunii.

Ale odkładając na bok porozumienie o zawieszeniu broni i analizując, czy ogólne zasady prawa międzynarodowego mogą stanowić podstawę żądań Rady Rządzącej poza podstawą rewolucyjną, która to Rada w braku regulacji prawnych nie może sprawować władzy państwowej, nie mając podstawy prawnej, ponieważ:

Zgodnie $\mathrm{z}$ art. 43 regulaminu międzynarodowej konwencji haskiej dotyczącej praw i zwyczajów wojny lądowej, uchwalonej ustawą nr XLIII z 1913 r., której regulamin stanowiący aneks do konwencji został zaakceptowany przez króla Rumunii i jako taki wiążący jest również dla tych, którzy przyłączyli się do Rumunii, okupant będzie sprawował władzę, przestrzegając prawa obowiązujące w tym kraju $^{38}$, art. 45 zaś zabrania przymuszania ludności terytoriów okupowanych do przysięgania na wierność państwu nieprzyjacielskiemu ${ }^{39}$. W związku z powyższym nie ma podstawy prawnej do przejęcia głównej władzy przez rumuńskie królewskie siły okupacyjne.

Tak więc dopóty, dopóki decyzje konferencji pokojowej nie ustalą ostatecznych granic powstających właśnie nowych państw i tak długo, dopóki ustawy uchwalone na mocy traktatu pokojowego - i tylko te, które można wziąć pod uwagę w celu uregulowania tej kwestii - nie zwolnią węgierskich urzędników państwowych od złożonej przysięgi, wszelkie postępowania mające na celu przejęcie sądów będących pod moim kierownictwem i nadzorem oraz zmuszenie pracowników wymiaru sprawiedliwości do złamania ślubów obywatelskich i tym samym zerwania więzi z państwem węgierskim powinny zostać uznane za niezgodne z prawem.

Ponieważ złożenie nowej przysięgi jest również kwestią osobistej odpowiedzialności, nie chciałem wpływać na nikogo, więc każdy sędzia i pracownik sądu apelacyjnego musi złożyć w tej sprawie osobne oświadczenie.

W związku z tym teraz, gdy protestuję przeciwko bezprawnym oczekiwaniom, których spełnienia muszę odmówić także z tego powodu, że procedura ta zniwe-

${ }^{38}$ Dokładny tekst przywołanego art. 43 brzmi następująco: „Z chwilą faktycznego przejścia władzy z rąk rządu legalnego do rąk okupanta tenże poweźmie wszystkie będące w jego mocy środki celem przywrócenia i zapewnienia, o ile to jest możliwem, porządku i życia społecznego, przestrzegając, z wyjątkiem bezwzględnych przeszkód, prawa obowiązujące w tym kraju”. Zwykle takie teksty obciążone są typowymi dla prawodawstwa międzynarodowego kompromisami, które rozluźniają rygor normatywny podobnymi sformułowaniami, jak: „wszystkie będące w jego mocy środki”, ,o ile to jest możliwem”, „Z wyjątkiem bezwzględnych przeszkód”.

39 Dokładny tekst: „Zabrania się przymuszania ludności terytorjów okupowanych do przysięgania na wierność państwu nieprzyjacielskiemu”. Stąd rumuńska interpretacja jest następująca: domaganie się przysięgi na wierność od ludności jest zabronione, ale urzędnicy, sędziowie, personel sądowy nie podlegają zakazowi konwencji haskiej. Zob. G. Iancu (red.), Justiție română..., s. 33. 
czy nienaganne dotychczas funkcjonowanie organów sądowych na okupowanym terenie, wyrażam moje własne stanowisko.

Odpowiedzialnością za wszelkie konsekwencje tej procedury obarczamy tych, którzy roszczą sobie prawo do przejęcia władzy ${ }^{40}$.

Po odczytaniu oświadczenia obecny przy tym sędzia Géza Nyírő oznajmił, że w zupełności zgadza się z jego treścią.

W odpowiedzi burmistrz dr Iulian Pop stwierdził, że nie respektuje porozumienia o zawieszeniu broni, ponieważ przy jego zawarciu Rumuni nie byli reprezentowani ${ }^{41}$, a podstawą ich roszczeń jest prawo narodów do samostanowienia, w szczególności zaś proklamacja, przyjęta jednogłośnie 1 grudnia 1918 r. na zgromadzeniu Rumunów siedmiogrodzkich w Gyulafehérvár, dlatego nie przyjmuje do wiadomości oświadczenia Antala Pozsonyiego, którego ponownie wezwał do opuszczenia sądu.

Antal Pozsonyi poprosił dowódcę armii o przedstawienie pisemnego rozkazu użycia wojska. Dr Iulian Pop oświadczył, że nie ma obowiązku przedstawienia takiego upoważnienia, ponieważ dekret Rady Rządowej dopuszcza skorzystanie również z pomocy sił zbrojnych.

Pozsonyi nie opuścił pomieszczenia dobrowolnie, dlatego dr Pop nakazał żandarmerii zająć budynek. Wejście do budynku zajęło wojsko rumuńskie, a wnętrze gmachu żandarmeria. Wkraczający do pomieszczenia sądowego żandarmi zmusili Antala Pozsonyiego i Gézę Nyírő do opuszczenia biura, de facto grożąc im kilkakrotnie użyciem broni.

Ioan P. Papp opisał ten opór i odmowę przekazania sądu z rumuńskiego punktu widzenia jako „z góry ukartowaną i diabelską myśl”, mającą na celu utrudnienie organizacji i konsolidacji rumuńskiego sądownictwa ${ }^{42}$. Motywację ideologiczną i nastrój panujący wśród rumuńskich sędziów przejmujących wymiar sprawiedliwości dobrze odzwierciedla nacjonalistyczne stanowisko Ioana P. Pappa, który mówił o tysiącletniej nienawiści węgierskich sędziów w Siedmiogrodzie wobec „ubranych w łapcie Rumunów” i ich obawach, żeby nie trafić pod rządy tych, których zwą pogardliwie wołosami [węg. oláhok-przyp. tłum.] $]^{43}$. Nota bene departament sprawiedliwości Rady Rządzącej również przeniósł się do budynku sądu apelacyjnego

${ }^{40}$ Wersję rumuńską zob. G. Iancu (red.), Justiție română..., s. 114-118; I.P. Papp, Instaurarea justiției românești..., s. 12-15.

${ }^{41}$ Rumunia nie mogła być reprezentowana, ponieważ 8 maja 1918 r. podpisała traktat pokojowy w Bukareszcie. 10 listopada 1918 r. ponownie wypowiedziała wojnę Niemcom (będącym wówczas jeszcze w stanie wojny), łamiąc tym pokój bukareszteński, aby zakończyć wojnę po zwycięskiej stronie. 11 listopada 1918 r. Niemcy podpisały rozejm w Compiègne, który zakończył I wojnę światową i utorował drogę traktatom pokojowym.

42 I.P. Papp, Instaurarea justiției românești..., s. 16.

${ }^{43}$ Ibidem, s. 19. 
w Klużu i kontynuował działalność nawet po rozwiązaniu Rady Rządzącej, które miało miejsce w 1920 r. - funkcjonował pod inną nazwą do $1924 \mathrm{r}$.

W tym miejscu warto uczynić małą dygresję. Drugi arbitraż wiedeński przywrócił Węgrom północny Siedmiogród (30 sierpnia 1940 r.), w wyniku czego część Siedmiogrodu została ponownie objęta węgierskim wymiarem sprawiedliwości. W styczniu 1941 r., podczas inauguracji prezesa sądu apelacyjnego Lajosa Vékása ${ }^{44}$ w Klużu, István Antal, wiceminister sprawiedliwości, przekazał mu niewielki pakunek. Była to węgierska flaga zerwana z gmachu sądu apelacyjnego 11 marca 1919 r. Flagę ocalił Antal Pozsonyi, który „przepasując się nią pod ubraniem, z narażeniem własnego życia przemycił flagę przez granice ustalone w Trianon" 45 . Flagę przechowano w archiwum Ministerstwa Sprawiedliwości. Jak relacjonował obecny przy tym wydarzeniu korespondent prasowy, wiceminister położył na stole spłowiałą, podniszczoną flagę. „W oczach uczestników błysnęły łzy... Dr Lajos Vékás drżącym, stłumionym od łez głosem podziękował za flagę i obiecał wiernie jej strzec" ${ }^{46}$. Z kolei artykuł zamieszczony na pierwszej stronie innej gazety tak komentował fakt uratowania flagi przez Antala Pozsonyiego:

Dawna flaga jest dziś oczywiście bezcennym skarbem dla Klużu. Ma nie tylko znaczenie symboliczne, ponieważ nie jest jedynie świadectwem poświęcenia i atencji, jaką dawny korpus sędziowski otaczał węgierską flagę z narażeniem życia, ale także prawdziwym, namacalnym reliktem, do którego nowe pokolenia prawników w wyzwolonym Siedmiogrodzie mogą odbywać godną pielgrzymkę. Szczególnym zrządzeniem losu w imieniu ministra sprawiedliwości flagę mógł przekazać urodzony na równinach Wielkiej Niziny Węgierskiej młody wiceminister sprawiedliwości, który do Siedmiogrodu zawitał po raz pierwszy, wygłaszając przy tym uroczyste przemówienie, $w$ którym potrzebę pogodzenia systemu prawnego ojczyzny z prawem Siedmiogrodu wyraził, ku zadowoleniu nas wszystkich, w duchu nadspodziewanie zgodnym $z$ duchem powszechnie kojarzonym z Siedmiogrodem. $\mathrm{W}$ istocie ta stara flaga symbolizuje też odwieczne prawo Siedmiogrodu. Prawo, w którym nigdy nie istniały różnice klasowe i wynikające z nich przywileje. Rzeczywiście, nic nie może godniej wyrazić poszanowania dla tej flagi i podniosłości ceremonii otwarcia prastarego sądu apelacyjnego w Klużu, jak wyrażona przez przedstawiciela ministra sprawiedliwości deklaracja poszanowania tych nieuznających społecznych przywilejów praw Siedmiogrodu i odpowiedzialna zapowiedź przeprowadzenia rządowego programu reformy najbardziej konserwatywnych anachronizmów prawa obowiązującego w macierzy w duchu praw siedmiogrodzkich $^{47}$.

${ }^{44}$ Był jednym z tych sędziów sądu okręgowego w Klużu, którzy w 1919 r. odmówili złożenia przysięgi.

45 „Keleti Ujság” z 18.01.1941 r., s. 5.

${ }^{46}$ Ibidem.

${ }^{47}$ „Ellenzék” z 18.01.1941 r., s. 1. 
Nota bene Antal Pozsonyi pozostał w Siedmiogrodzie i został liderem ruchu walczącego o roztrzygnięcie kwestii węgierskich urzędników. Nie mogąc jednak wykorzystywać swojej wiedzy prawniczej, w 1923 r. przeniósł się do Budapesztu (repatriował), gdzie został mianowany przewodniczącym rady sądu apelacyjnego w Budapeszcie, potem zaś przeniesiony do Ministerstwa Sprawiedliwości, a następnie do sądu odpowiedzialnego za uporządkowanie stosunków własnościowych gruntów (Földbirtokrendező Bíróság). Zmarł w 1932 r.

Jak już wspomniano, przejęcie sądu okręgowego w Klużu miało miejsce 11 marca. Prezes sądu okręgowego, dr Béla Ternovszky, nie uznał uprawnień i dekretów rumuńskiej Rady Rządzącej, ponieważ na podstawie porozumienia o zawieszeniu broni zawartego z mocarstwami sprzymierzonymi sądownictwo cywilne miało podlegać węgierskiemu rządowi. Kiedy w budynku pojawiła się żandarmeria, Béla Ternovszky przekazał sąd i opuścił gmach. Na zebraniu 12 marca, zwołanym przez dr. Laurențiu Nestora, mianowanego prezesa rumuńskiego sądu, w celu złożenia przysięgi na wierność nie pojawił się nikt. Nestor zwrócił się do departamentu sprawiedliwości Rady Rządzącej ze skargą: „Zostałem całkowicie bez sędziów i nie mam żadnego personelu" ${ }^{48}$. Z tego względu na 14 dni trzeba było zawiesić działalność sądu. Podczas przejęcia miejskiego sądu rejonowego, które miało miejsce 17 marca 1919 r., Miklós Gáspár, prezes sądu rejonowego, i dwaj inni obecni sędziowie, László Kálnássy i János Hofbauer, zostali usunięci z budynku przy faktycznym użyciu siły. Przejęcie powiatowego sądu rejonowego w Klużu odbyło się tego samego dnia, ale szczegółów tego przejęcia nie udało się jeszcze wyjaśnić.

W chwili podpisania traktatu pokojowego w Trianon 4 czerwca 1920 r. w Siedmiogrodzie działało już utworzone w wyżej opisany sposób rumuńskie sądownictwo.

\section{PRZEJĘCIE IZBY ADWOKACKIEJ W MAROSVÁSÁRHELY}

Kiedy nastąpiła zmiana imperium, Andor Fekete, adwokat z Marosvásárhely, miał już za sobą dziesięć lat praktyki. Adwokatów z Marosvásárhely wezwano do złożenia przysięgi na wierność państwu rumuńskiemu w kwietniu 1919 r. Większość z nich, z wyjątkiem trzech, odmówiła złożenia przysięgi. Ci z adwokatów, którzy pragnęli pozostać w Siedmiogrodzie, również obawiali się, że fakt złożenia przysięgi zostanie wykorzystany w negocjacjach pokojowych jako argument przeciwko Węgrom i potraktowany jako dobrowolne uznanie władzy Rumunii. Wciąż istniała nadzieja na osiągnięcie sprawiedliwego traktatu pokojowego.

${ }^{48}$ G. Iancu (red.), Justiţie română..., s. 124. 
György Repede ${ }^{49}$, prezes sądu okręgowego, i Constantin Popa, kapitan żandarmerii, 1 lipca 1919 r. zjawili się w Izbie adwokackiej ${ }^{50}$, aby ją przejąć. W imieniu zarządu aktu przekazania odmówił m.in. mecenas Andor Fekete, członek zarządu i sędzia dyscyplinarny. Na zebraniu przygotowującym spotkanie z władzami rumuńskimi Fekete najostrzej sprzeciwiał się przekazaniu Izby, co zresztą Repede i Popa słyszeli, czekając w sąsiednim pomieszczeniu ${ }^{51}$. Jednym z jego argumentów było to, że „Traktat pokojowy między Węgrami a Rumunią nie został jeszcze podpisany. Zatem suwerenność nie przeszła jeszcze na Rumunię. Wniosek o przejęcie jest więc nieuzasadniony, dlatego zarząd Izby odmawia jego spełnienia"s2.

Repede, prezes sądu okręgowego, kipiąc ze złości, zaprotestował przeciwko stanowisku wyrażonemu przez dr. Andora Fekete, które zakwalifikował jako zbrodnię przeciwko państwu rumuńskiemu. Oświadczył, że od grudnia 1918 r., kiedy armia rumuńska wkroczyła do Siedmiogrodu, ten należy do Rumunii. Fekete podtrzymał jednak swoje dotychczasowe zdanie.

Okupacja armii rumuńskiej jest niezależna od kwestii suwerenności. Wyrażone stanowisko nie jest więc zamachem przeciwko państwu rumuńskiemu, tylko zdaniem opartym na prawie międzynarodowym, którego Izba adwokacka nie może w żadnym wypadku zlekceważyć. Poprosił o odnotowanie w protokole swojego protestu i jego uzasadnienia ${ }^{53}$.

Protokół ostatecznie nie został sporządzony, a kapitan żandarmerii stwierdził, że wobec zgłoszonego protestu Izba adwokacka zostanie przejęta siłą. Tak też się stało: przejęto archiwum i majątek Izby. Nie znaleziono jednak opatrzonej węgierskim herbem pieczęci Izby. Pieczęć odnalazła się po drugim arbitrażu wiedeńskim, kiedy północny Siedmiogród powrócił (na krótki czas) do Węgier. Okazało się wtedy, że została ukryta przez kierownika biura Izby adwokackiej ${ }^{54}$.

Postawa Andora Feketego nie pozostała bez retorsji. W nocy 2 lipca 1919 r. dwóch rumuńskich agentów bezpieki zabrało go z mieszkania.

${ }^{49}$ George (gdzie indziej: Gheorghe) Repede. Zastępca sekretarza, a następnie sekretarz w sądzie rejonowym w Kőhalom (rum. Rupea). W 1910 r. został przeniesiony do Dicsőszentmárton (rum. Târnăveni), w 1913 r. mianowany tam sędzią rejonowym, od 1914 r. sędzia rejonowy w Nagymihály (słow. Michalovce).

${ }^{50}$ W tym czasie Izba Adwokacka w Marosvásárhely obejmowała dystrykty sądów okręgowych w Marosvásárhely, Bystrzycy, Csíkszeredzie i Székelyudvarhely.

${ }^{51}$ A. Fekete, Közélet és kaszinó, Marosvásárhely 2019, s. 55.

${ }^{52}$ Por. Spotkanie dwóch dat: 22 lata przed utworzeniem Izby Adwokackiej na Seklerszczyźnie, Rumuni siła przejęli Izbę Adwokacka w Marosvásárhely. Członka zarzadu, który odmówił przekazania organu, noca zabrali z mieszkania agenci bezpieki, „Keleti Újság” z 2.07.1941 r., s. 6.

53 Ibidem.

${ }^{54}$ Por. „Keleti Újság” z 24.09.1941 r., s. 3. 
Zarzucając mu w powozie na głowę gumowe prześcieradło, obaj zaczęli go dusić. Zdołał uniknąć pewnej śmierci tylko w ten sposób, że używając resztek sił, wyrwał się z rąk swoich oprawców i wyskoczył z pędzącego powozu na jezdnię, roztrzaskując kończyny. Stamtąd zabrali go do domu sascy oficerowie, którzy natknęli się na niego przypadkowo. Leżał ranny przez wiele tygodni pod stałą strażą tajnych detektywów, żeby z nikim nie mógł rozmawiać ${ }^{55}$.

Tylne koło konnego powozu przejechało po obu jego nogach.

Dr Albert Kovácsy, notariusz królewski, który przed I wojną światową był posłem do parlamentu w Budapeszcie, razem z Iuliu Maniu, przewodniczącym Rady Rządzącej z Sybinu, interweniował w sprawie Andora Feketego i dzięki niemu postępowanie zostało umorzone. Po odzyskaniu zdrowia Fekete został przesłuchany przez szefa tajnych służb w Marosvásárhely, Teodora Pașca, ale zgodnie z instrukcjami Maniu adwokatowi, który swego czasu odmówił przekazania Izby adwokackiej, można było tylko udzielić upomnienia.

To upomnienie jednak wcale nie powstrzymało mnie od tego, żebym od pierwszej chwili poczuwał się do obowiązku uczestnictwa we wszystkich działaniach węgierskiego ruchu politycznego. W pierwszych latach rządów rumuńskich byłem kilkakrotnie aresztowany w różnych, często bardzo poważnych okolicznościach. Ale ostatecznie we wszystkich przypadkach byłem zwalniany. Nigdy nie brałem bowiem udziału w żadnej nielegalnej działalności. Zawsze reprezentowałem poglądy zgodne z prawami przyznanymi Węgrom na arenie międzynarodowej. A to nie było łamaniem prawa ${ }^{56}$.

W dniu 31 grudnia 1921 r. na obszarze należącym do Izby w Marosvásárhely było już tylko 99 węgierskich adwokatów, o 57 mniej niż w 1914 r., nadal jednak stanowili większość palestry, odpowiednio zresztą do tego, że obszar Izby należał w Siedmiogrodzie do terenów zamieszkanych przez Węgrów w największej części ${ }^{57}$. Mimo to do władz Izby adwokackiej wszedł tylko jeden Węgier. We wrześniu 1921 r. Andor Fekete mógł ponownie otworzyć swoją kancelarię ${ }^{58}$.

\section{DZIAŁALNOŚĆ WYMIARU SPRAWIEDLIWOŚCI: PRZYPADEK SEPSISZENTGYÖRGY}

W jaki sposób można było przeprowadzić w sądownictwie zmiany personalne i zamianę języka w tych częściach Siedmiogrodu, w których Węgrzy stanowili

${ }^{55}$ Spotkanie dwóch dat..., s. 6.

56 A. Fekete, Közélet és kaszinó, s. 57.

${ }^{57}$ W 1923 r. dużą, rozciągającą się na kilka okręgów Izbę rozwiązano, a w jej miejsce utworzono osobne Izby w każdym okręgu.

${ }^{58}$ Por. „Székely Nép” z 10.09.1921 r., s. 4. 
większość populacji? Państwo rumuńskie nie zamierzało podtrzymać tymczasowego przeniesienia reżimu językowego węgierskiej ustawy o mniejszościach narodowych, a fragmenty proklamacji z Gyulafehérvár dotyczące wymiaru sprawiedliwości zostały zignorowane. Aurel Lazăr oświadczył w 1919 r.:

[...] oficjalnym językiem państwa jest rumuński, ale do czasu rozstrzygnięcia tej kwestii będą wdrażane szeroko interpretowane przepisy ustawy nr XLIV z 1868 r., z tą poprawką, że tam, gdzie mowa jest o języku węgierskim, należy rozumieć język rumuński. Zatem sądownictwo będzie dostępne dla wszystkich w ich ojczystym języku. Na naukę języka rumuńskiego przeznacza się rok, który to termin może ulec przedłużeniu ${ }^{59}$.

Natomiast rozporządzenie Dyrekcji Generalnej Rumuńskiego Ministerstwa Sprawiedliwości w Klużu z dnia 11 stycznia 1921 r. nakładało na sądy obowiązek używania języka rumuńskiego, nie dopuszczając wyjątku od tej reguły. Zaś rozporządzenie nr 19.654 z dnia 1 września 1922 r. wprowadziło wyłączne stosowanie języka rumuńskiego w sądach jako organach rejestru gruntów. Rumuńska konstytucja z 1923 r. ustanowiła, że „rumuński jest językiem urzędowym Rumunii” (art. 126). Po wydaniu wspomnianego rozporządzenia (dekretu) prezes sądu apelacyjnego w Oradei o węgierskim nazwisku wydał okólnik w języku rumuńskim i węgierskim, który przewidywał, że ,językiem urzędowym sądów jest język rumuński, którego zarówno sędziowie, jak i adwokaci mają obowiązek używać bez wyjątku tak w piśmie, jak i w słowie, we wnioskach i na rozprawach"60.

Przejęcie wymiaru sprawiedliwości było specyficzną kwestią na Seklerszczyźnie, gdzie nie było miejscowej palestry posługującej sięjęzykiem rumuńskim, której można by powierzyć trudne zadanie reorganizacji wymiaru sprawiedliwości. Sąd okręgowy w Csíkszereda (rum. Miercurea Ciuc) został przejęty dopiero 28 lipca 1919 r., tutaj również cały personel odmówił złożenia przysięgi. Ponieważ nie można było znaleźć natychmiastowego rozwiązania, sąd został tymczasowo zamknięty, a jego funkcje przejął sąd okręgowy w Braszowie. Również sąd rejonowy trzeba było tymczasowo zamknąć. To samo stało się w Kézdivásárhely (rum. Târgu Secuiesc). Procedura powtórzyła się w kilku innych sądach rejonowych na Seklerszczyźnie. Personel sądu rejonowego w Székelyudvarhely (rum. Odorheiu Secuiesc) również odmówił złożenia przysięgi. Tu jednak ,po odmowie złożenia przysięgi, ponieważ nikt się nie poddał i nie mieli ludzi, byliby zmuszeni do zamknięcia sądów, Valér Neamţiu ogłosił więc przejęcie władzy nad sądami, poważnymi groźbami zmuszając cały personel do pozostania na miejscu aż do nadejścia zastępstwa" ${ }^{61}$.

${ }^{59} \mathrm{Z}$ mowy wygłoszonej podczas przejęcia sądu okręgowego w Oradei. Por. G. Iancu (red.), Justiție română..., s. 334.

${ }^{60}$ Por. „Honszeretet” z 16.04.1921 r., nr 6, s. 9.

${ }^{61}$ N. Bárdi, Impériumváltás Székelyudvarhelyen 1918-1920, „Aetas” 1993, nr 3, s. 101. 
Jako przedmiot analizy działalności sądownictwa autor wybrał leżącą na Seklerszczyźnie miejscowość Sepsiszentgyörgy. Jest to przypadek nietypowy, ponieważ sąd królewski w Sepsiszentgyörgy został zniesiony w 1875 r. (połączony został z sądem w Kézdivásárhely ${ }^{62}$. Oznaczało to, że w Sepsiszentgyörgy nie nastąpiło przejęcie sądownictwa, tylko powołanie nowego rumuńskego sądu okręgowego w 1923 r., już po traktacie z Trianon. Skład etniczny Sepsiszentgyörgy w 1920 r. przedstawiał się następująco: Węgrzy - 83,5\%, Rumuni - 11,9\%, Żydzi - 2,5\%, Niemcy - 1,8\%. Obraz faktycznej działalności sądownictwa można zrekonstruować na podstawie wywiadów z osobami żyjącymi w tamtych czasach. O sędziach $\mathrm{z}$ terytorium starego królestwa wspominano tak:

[...] do sądu okręgowego nastawali tacy sędziowie, którzy kończyli studia w Paryżu i byli potomkami zamożnych rodzin bojarskich. Próbowali się tutaj zachowywać na zachodnią modłę. Wiedział taki, że jeśli tu mieszka, to musi złożyć wizytę u znaczniejszego z palestry. Robił więc to, i to dokładnie tak, jak przystało na hiszpańską etykietę: ubrany na czarno, wysyłał wizytówkę, jak trzeba, i oczywiście zostawał zaproszony. Czyli starali się, żeby nie dać odczuć zgrzytów, które i tak podzieliły nasz świat... ${ }^{63}$

Wraz z sędziami z terytorium starego królestwa w Siedmiogrodzie pojawiła się też całkiem inna kultura prawnicza. „Też sędziowie, niejeden z nich bardzo inteligentny prawnik, ale byli to typowi królewiacy, którzy nie mieli oporów przed przyjęciem skromnych upominków" "64. Większość sędziów była Rumunami, w pamięci wielu osób żywy jest tylko jeden sędzia Węgier, Gyula Tana ${ }^{65}$, nadmieniano również, że „był jakiś sędzia węgiersko-ormiański, niejaki Viktor Verzár ${ }^{66}$, ale ten nie rzucał się w oczy za bardzo" ${ }^{67}$. Jednak księgi wieczyste były zawsze prowadzone przez Węgrów.

Rozprawy toczyły się z reguły w języku rumuńskim, a sędziowie z terytorium starego królestwa korzystali z tłumaczy. Gyula Tana ,pochodził z rodziny właścicieli ziemskich w Bölön (rum. Belin), a chociaż nie mówił dobrze po rumuńsku, był niezwykle przyzwoitym człowiekiem, co doceniły w nim nawet rumuńskie władze...”68. Część węgierskich adwokatów też kaleczyła rumuński; bywało, że

${ }^{62}$ S. Tóth, A háromszéki királyi törvényszék székhelyéért folytatott küzdelem, 1875, Acta Siculica. A Székely Nemzeti Múzeum évkönyve, Sepsiszentgyörgy 2009, s. 453-500.

${ }^{63}$ A.B. Kovács, Szétszabdalt Székelyföld. Háromszéki helytörténeti irások, Marosvásárhely 2006, s. 63.

${ }^{64}$ Ibidem, s. 97.

${ }^{65}$ Ibidem, s. 64-65. W rzeczywistości w Sepsiszentgyörgy pracowało jednocześnie kilku sędziów węgierskich, oprócz Gyuli Tany np. Pál Emil Nagy i Kristóf Zakariás. Por. „Székely Nép” z 6.04.1924 r., s. 3 .

${ }^{66}$ Viktor Verzár.

${ }^{67}$ A.B. Kovács, Szétszabdalt Székelyföld..., s. 97.

${ }^{68}$ Ibidem. 
niektórzy wysławiali się w połowie w jednym, w połowie w drugim języku. Nawiasem mówiąc, niejeden z rumuńskich sędziów w Siedmiogrodzie płynnie mówił po węgierskư ${ }^{69}$.

Ciekawostką jest to, że Gyula Tana został prezesem węgierskiego sądu okręgowego w Sepsiszentgyörgy w 1943 r., kiedy na mocy drugiego arbitrażu wiedeńskiego północna część Siedmiogrodu została włączona z powrotem do Węgier. W laudacji od sędziów podkreślano, że Gyula Tana wiernie wypełniał swój zawód sędziego w sercu Seklerszczyzny nawet pod obcą władzą, poświęcając osobiste interesy. W laudacji od palestry jako główną zasługę Tany uwypuklono to, że pod obcymi rządami nie porzucił swoich najpoważniejszych obowiązków wtedy, kiedy węgierski sędziowie i adwokaci błądzili w ciemnościach osieroceni, tylko trwał na swoim miejscu, żeby służyć sprawiedliwości tego narodu, który, wydarty macierzy, stał bezradny w wielkim świecie ${ }^{70}$. Innymi słowy, Gyula Tana nie skompromitował się nawet jako sędzia rumuński.

Sędziowie rumuńscy zmieniali się dość często. Na przykład w 1937 r. lokalna prasa podała, że w sądzie rejonowym w Sepsiszentgyörgy nastała smutna sytuacja:

W sądzie rejonowym, którego jurysdykcji podlega czterdzieści pięć gmin, w którym dotychczas nawet praca trzech sędziów była niewystarczająca, pozostał na służbie jeden tylko, któremu pozostaje wybór, czy zarządzać sprawami administracyjnymi sądu, czy rozpoznawać sprawy procesowe. Naturalnie terminowe rozpatrywanie spraw jest fizycznie niemożliwe, więc petenci ponoszą z tego powodu rozliczne szkody ${ }^{71}$.

Inną osobliwością sądownictwa w tym okresie - pozostając teraz wyłącznie na gruncie norm prawa cywilnego - było to, że w obrębie historycznego Siedmiogrodu obowiązywał austriacki kodeks cywilny (ze zmianami i ustawodawstwem wprowadzonym przez węgierskie prawo od 1867 r.), natomiast w obrębie pozostałych terenów przyłączonych do Rumunii kosztem Węgier obowiązywały przepisy węgierskiego prawa cywilnego powstałe przed 1 grudnia 1918 r., a więc historyczne węgierskie prawo zwyczajowe. Na całym terytorium przyłączonym do Rumunii obowiązywały ustawa nr I z 1911 r. o kodeksie postępowania cywil-

${ }^{69}$ We wspomnieniach z epoki czytamy, jak jeden z rumuńskich sędziów „,zakochał się w pięknej Węgierce i smalił do niej cholewki. To przypomniało mi się w związku ze znajomością języka. Jego rodzina była temu przeciwna, co doprowadziło do tragedii. Dziewczyna napisała list pożegnalny, zdobyła gdzieś pistolet, w cukierni na rogu Mikó (tam, gdzie teraz jest samoobsługowy) zaczekała, aż on będzie przechodził - sąd rejonowy był w Domu zwanym Rondlem - strzeliła mu dwa razy w plecy, a sobie w głowę. Ona zginęła, on nie, ale strzał w kręgosłup sparaliżował go do końca życia. Chodziłam wtedy do pierwszej klasy gimnazjum. Całe miasto było bardzo poruszone tą sprawą". Ibidem, s. 97-98.

${ }^{70}$ „Székely Nép” z 18.11.1943 r., s. 3.

71 „Székely Nép” z 18.07.1937 r. 
nego (siedmiogrodzki kodeks postępowania cywilnego) oraz ustawa nr XXXVII z 1875 r. o prawie handlowym (siedmigrodzki kodeks handlowy). Rozpoczęło się również ujednolicanie prawa, ale był to proces trwający dziesięciolecia, co oznacza, że w okresie międzywojennym sądy rumuńskie w wielu przypadkach stosowały prawo węgierskie w języku rumuńskim ${ }^{72}$. Innymi słowy, w całym okresie międzywojennym sądownictwo Siedmiogrodu było naznaczone tymczasowością - pomimo błyskawicznego przejęcia struktur i podporządkowania ich rumuńskim władzom, ujednolicenie prawa było złożonym i czasochłonnym procesem, głównie dlatego, że zwykłe przejęcie porządku prawnego starego królestwa, który pod wieloma względami wymagał reform, nie leżało w interesie rumuńskiej elity prawników w Siedmiogrodzie.

\section{WNIOSKI}

Nie ulega wątpliwości, że odbywające się przy wsparciu wojska przejęcie struktury sądownictwa przed ostatecznym rozstrzygnięciem prawnym losu regionu było naruszeniem istniejącego porządku prawnego. Rumuńska polityka zjednoczenia, wykorzystująca przede wszystkim silne wsparcie polityczne Francji i obecność armii rumuńskiej w Siedmiogrodzie, przejmując struktury administracji i sądownictwa, miała na celu postawienie konferencji pokojowej przed faktem dokonanym, co miało zapewnić pomyślny z rumuńskiej perspektywy finał powojennego porozumienia. Wykraczające poza normy prawne przejęcie struktur sądowych zostało jednak post factum usprawiedliwione i uświęcone w 1920 r. traktatem pokojowym w Trianon, który rozstrzygnął losy spornych terytoriów po myśli Rumunów. Znaczna liczba adwokatów i sędziów, którzy odmówili złożenia przysięgi, kontynuowała karierę w potrianońskich granicach Węgier. Inni pozostali na miejscu i starali się dostosować do nowych porządków w sądownictwie, ewentualnie zmienić zawód, żeby stawić czoło realiom określonym przez status mniejszościowy.

przekład: Anna Jakubowska

${ }^{72} \mathrm{Na}$ temat przetrwania węgierskiego prawa postępowania cywilnego zob. E. Veress, A jogegységesités útvesztői. Polgári perjog Erdélyben 1928/1920 és 1945 között, „Rubicon” 2019, nr 9-10. Na temat prawa własności: idem, Kilenc évtized - az Osztrák Általános Polgári Törvénykönyv Erdélyben [w:] E. Veress (red.), Ad salutem civium inventas esse leges. Tisztelgö kötet Vékás Lajos 80. születésnapjára, Kolozsvár 2019, s. 157-171. 


\title{
TAKING OVER THE STRUCTURES OF THE JUDICIARY \\ IN TRANSYLVANIA IN 1919
}

\begin{abstract}
At the end of 1918, a significant part of Transylvania, a multinational and historical region belonging to Hungary, came under the military occupation of Romania. In the spring and summer of 1919, the judiciary was taken over in the geographic territories which were under the Romanian army's control. The article attempts to answer how de jure and de facto this takeover took place - in the grey area of the change of sovereignty - as the final fate of this territory, its annexation by Romania, was decided on the $4^{\text {th }}$ of June 1920 as a result of the Treaty of Trianon. The article raises several interesting questions: the achievement of legality in general and the limits of the law, and in particular the nature of the transitional period and its characteristic legal changes.
\end{abstract}

Keywords: World War I, Transylvania, takeover of courts, transfer of sovereignty, Treaty of Trianon 